\section{Lytvyn V., Uhryn D., Olyvko R., Borovets Ya.}

\title{
DEVELOPMENT OF A DISCRETE OPTIMIZATION OPERATION SOLUTION INFORMATION TECHNOLOGIES BASED ON SWARM INTELILIGENCE
}

Об'єктом даного дослідження є процедура побудови інформаційних технологій, функиіонування яких базується на методах ройового інтелекту, для розв'язування задач дискретної оптимізації.

Для розв'язування будь-якої задачі оптимізащї в множині ройових алгоритмів, напевно знайдеться хоча б один алгоритм, який дасть, як мінімум, задовільні результати. Однак, немає і не може бути алгоритму, який міг би забезпечити високу ефективність при вирішенні всіх задач оптимізації. Тому для кожного $з$ ройових алгоритмів можуть бути виділені класи завдань, які він вирішує: краще за інші алгоритми; приблизно як інші алгоритми; гірше інших алгоритмів.

В ході дослідження використовувалися інформаційні технологї розв'язування задач дискретної оптимізацї на основі ройових алгоритмів. Отримано методи застосування різного класу алгоритмів ройового інтелекту для розв'язування задач дискретної оптимізаиї. Поєднано методи ройового інтелекту для розв'язування певного класу задач. Визначено оптимальні значення параметрів певних методів ройового інтелекту.

Розроблено інформаційну технологію використання ройових алгоритмів у залежності від класу задачі дискретної оптимізації, який грунтується на характеристиках ройових алгоритмів (вид вхідних параметрів, окіл популящій, тип формування популяцій, тип ітераційних процесів). Це дало змогу обирати релевантний ройовий алгоритм для розв'язування прикладних задач та класифікувати ці задачі в залежності від характеристик ройових алгоритмів, який використовується для ї розв'язання.

Розроблено інформаційну технологію використання сукупності різних методів ройових алгоритмів для розв'язування певного класу задач, що, на відміну від інших підходів, базується на гібридному підході використання ройових алгоритмів в залежності від їх характеристик. Це дає змогу використати перевагу певного ройового алгоритму й тим самим підвищити ефективність розв'язування певних класів прикладних задач дискретної оптимізачї.

Ключові слова: Әискретна оптимізація, ройовий інтелект, інформаційні технологї, системи підтримки прийняття рішень.

\section{Introduction}

The features of global optimization problems explain the absence of a universal algorithm for their solution and, conversely, the presence of a significant number of algorithms, their modifications and hybridization. To effectively solve discrete optimization problems in the 1980s began to intensively develop a class of stochastic search optimization algorithms, which in various publications are called behavioral, intellectual, meta-heuristic, inspired by nature, swarm, multi-agent, population, etc. Swarm algorithms involve the simultaneous processing of several options for solving the optimization problem and represent an alternative the classic «trajectory» search algorithms, in which only one candidate for solving this problem evolves in the search area that task.

The overwhelming majority of the considered algorithms are published in the English-language literature, in which the term «algorithm» is used instead of the traditional for the Ukrainian reader term «method». In order to avoid the possible ambiguity of identifying the considered objects, the deadline is also used, although it is not entirely correct from the point of view of Ukrainian-language publications.

All swarm algorithms belong to the class of heuristic algorithms, that is, algorithms for which the convergence to the solution has not been proven, but it has been estab- lished experimentally that in most cases they give a fairly good solution. One of the peculiarities of swarm algorithms is that in the overwhelming majority of cases, they have a rather interesting analogy in human society, living or inanimate nature. So, the swarm algorithms of mind evolution, ant colonies, swarming bees, fireflies, gravitational and electromagnetic search, etc. are known.

The paper proposes the solution of this actual scientific and applied problem in the form of theoretically grounded models for solving discrete optimization (DO) problems based on swarm algorithms. The essence of these models and methods is:

- scientific substantiation of the use of various classes of swarm intelligence methods for solving DO problems; - combination of methods of swarm intelligence for solving a certain class of problems;

- determine the optimal values of the parameters of certain methods of swarm intelligence.

\section{The object of research and its technological audit}

The object of research is the procedure of building information technologies, the functioning of which is based on the methods of swarm intelligence, for solving DO problems. 
The task of global optimization is a significant number of applied tasks:

- optimization on networks;

- traffic routing in communication networks;

- task of placing economic objects;

- task of optimizing automated resource planning systems;

- logistics tasks;

- tasks of artificial intelligence and robotics, and the like.

The peculiarities of such tasks are often non-linearity, undifferentiated behavior, multi-modal nature, lack of analytical expression (poor formality) and high computational complexity of optimized functions, high dimension of the search space, complex topology of the range of acceptable values, etc.

Compared to classical methods, swarm algorithms have indisputable advantages, first of all, in solving problems of high dimension, multimodal and poorly formalized problems. Under these conditions, swarm algorithms can provide a high probability of localizing the global extremum of the optimized function. It is also important that population algorithms allow more efficiently, than classical algorithms, to find a suboptimal (close to optimal) solution. Just such a solution is often enough. Obviously, it does not make sense to use swarm algorithms for small-scale problems, since it is always possible to find the optimal solution using the full brute force method.

The disadvantages of population-based algorithms should also include a strong dependence of their efficiency on the values of free parameters, the number of which in most algorithms is quite large.

To solve any optimization problem in the plurality of swarm algorithms, there will surely be at least one algorithm that will give at least satisfactory results. However, there is not and can't be an algorithm that could provide high efficiency in solving all optimization problems. Therefore, for each of the swarm algorithms, classes of problems that it solves can be distinguished: algorithms are better than others; something like other algorithms; worse than other algorithms.

\section{The aim and objectives of research}

The aim of research is development of information technologies for solving discrete optimization problems based on swarm intelligence algorithms.

To achieve this aim it is necessary:

1. To analyze the specifics of the DO problems and the methods of swarm intelligence to solve them, by classifying them.

2. To carry out the development of information technology using the methods of swarm intelligence for solving DO problems.

3. To carry out the development of information technology a combination of individual methods of swarm intelligence for solving a certain class of DO problems.

\section{Research of existing solutions of the problem}

To solve any optimization problem in the plurality of swarm algorithms, there will surely be at least one algorithm that will give at least satisfactory results. However, there is not and can't be an algorithm that could provide high efficiency in solving all optimization problems. Therefore, for each of the swarm algorithms, classes of tasks that it solves can be distinguished:

- better than other algorithms;

- approximately as other algorithms;

- worse than other algorithms.

The disadvantages of population-based algorithms should also include a strong dependence of their efficiency on the values of free parameters, the number of which in most algorithms is quite large.

Summing up the above, the scientific contradiction lies in the fact that, on the one hand, a significant number of applied tasks is reduced to discrete optimization problems, and on the other hand, the amount of information that needs to be processed grows at a significant pace. This makes it impossible to use classical methods for solving DO problems. Therefore, to solve them, it is advisable to use swarm algorithms, but for a certain class of DO problems, not all swarm algorithms provide satisfactory solutions.

The use of swarm algorithms for solving discrete optimization applied problems has been described in many literary sources, however, one of them does not provide a rationale: why this particular algorithm was used to solve a specific problem. Table 1 gives the analysis of literary sources, a list of tasks that are solved by swarm algorithms

Tahle 1

Types of population algorithms

\begin{tabular}{|c|c|c|}
\hline Optimization problems & Swarm algorithm & $\begin{array}{c}\text { No. } \\
\text { of source }\end{array}$ \\
\hline $\begin{array}{l}\text { Search for a rational path on a graph; } \\
\text { traveling salesman problem; schedu- } \\
\text { ling task; calculations of computer and } \\
\text { telecommunication networks; graph } \\
\text { coloring task; network traffic optimiza- } \\
\text { tion problem }\end{array}$ & $\begin{array}{l}\text { Ant Colony Algorithm } \\
\text { Algorithms and Its } \\
\text { Modifications }\end{array}$ & {$[1-3]$} \\
\hline $\begin{array}{l}\text { Solving the problem of scheduling; } \\
\text { traveling salesman tasks; transporta- } \\
\text { tion task; management optimization; } \\
\text { classifier optimization }\end{array}$ & $\begin{array}{l}\text { Bee Colony Optimization } \\
\text { Method and Modifica- } \\
\text { tions }\end{array}$ & {$[4,5]$} \\
\hline $\begin{array}{l}\text { Solving nonlinear transport problems; } \\
\text { scheduling tasks; machine learning } \\
\text { tasks; tasks of optimization of functions } \\
\text { of many parameters, shapes, sizes and } \\
\text { topologies; design area; bioenginee- } \\
\text { ring, biomechanics, biochemistry }\end{array}$ & $\begin{array}{l}\text { Particle Swarm Optimi- } \\
\text { zation Algorithm }\end{array}$ & {$[6-8]$} \\
\hline $\begin{array}{l}\text { Iteration to obtain a global minimum } \\
\text { (or maximum) }\end{array}$ & $\begin{array}{c}\text { Differential Evolution } \\
\text { Methad }\end{array}$ & [9] \\
\hline Food search algorithm & Gray Wolf Algorithm & {$[10,11]$} \\
\hline $\begin{array}{l}\text { Search for points and areas by local } \\
\text { minimum and maximum }\end{array}$ & Bat-Inspired Algorithm & [12-14] \\
\hline Distribution search algorithm & $\begin{array}{l}\text { Shuffled Frog Leaping } \\
\text { Algorithm }\end{array}$ & [15] \\
\hline $\begin{array}{l}\text { Solving optimization and modeling } \\
\text { problems by sequential selection, com- } \\
\text { bination and variation of the desired } \\
\text { parameters }\end{array}$ & Genetic Algorithm & [16] \\
\hline $\begin{array}{l}\text { Solving problems of multi-dimensional } \\
\text { continuous optimization }\end{array}$ & $\begin{array}{l}\text { Migrating Bird Optimi- } \\
\text { zation Algorithm }\end{array}$ & [17] \\
\hline
\end{tabular}


On the basis of the conducted literary analysis, it is possible to conclude that a problem arises - the development of a methodology for using methods of swarm intelligence for solving a certain class of DO problems. In $[18,19]$, the authors of this study made the first attempt to build such a methodology, however, without taking into account the specifics of the swarm algorithms. In this paper, the authors propose to describe the swarm algorithms by seven signs.

\section{Methods of research}

The problem of discrete optimization is the task of finding the maximum or minimum of a function $f$ defined on a finite or countable set $D$ :

$$
f(x) \rightarrow e x t r, x \in D .
$$

Function $f$ is called an objective function, and the elements of a set $D$ are admissible solutions. If the set $D$ is set by the constraint system:

$$
\begin{aligned}
& g_{i}(x) \leq 0, i=1, \ldots, m_{1}, g_{i}(x)=0, i=m_{1}+1, \ldots, m, \\
& x=\left(x_{1}, \ldots, x_{n}\right) \in R_{n}, x_{j} \in \Omega_{j} \subset R, j=1, \ldots, n_{1}, n_{1} \leq n,
\end{aligned}
$$

where each $\Omega_{j}$ - either a finite set containing at least two elements, or a countable set.

The general scheme of swarm algorithms includes the following steps:

1. Population initialization. In the search area, in one way or another let's create a certain number of initial approximations to the desired solution of the problem it initializes the population of agents.

2. Migration of the population agents. With the help of a certain set of migration operators specific for each of the swarm algorithms, let's move agents in the search area in such a way as to ultimately get closer to the desired extremum of the function, is optimized.

3. Finishing the search. Let's check the fulfillment of the conditions of the end of the iterations and, if they are satisfied, let's complete the calculations, taking the best of the found positions of the population agents as an approximate solution of the problem. If the specified conditions are not met, we return to performing step 2 .

As a search end, as a rule, the condition of reaching a given number of iterations (generations) is used. Often, the stagnation condition of the algorithm is also used; when the function's better achieved value is optimized, it does not change for a given number of generations. Other conditions can be used, for example, the condition of a given time allowed for solving a problem.

The most important concept of swarm algorithms is the concept of a fitness function. Often this function is called the function of fitness, utility function, function of fitness, etc. The importance of the function is due to the fact that it is used to evaluate the «quality» of population agents. Strategically, in the process of migration, agents move in such a way as to approach the global extremum of the fitness function. One of the main problems in the design of swarm algorithms is ensuring a balance between the search intensity (the rate of convergence of the algorithm) and the search width (search diversification). The main criteria for the effectiveness of swarm algorithms is the reliability of the algorithm - an estimate of the localization probability of the global extremum, as well as its rate of convergence - an estimate of the expectation of the required number of tests (calculations of the optimized function value).

\section{Research results}

The features of the global optimization problems that are currently emerging in many applications are:

- nonlinearity;

- lack of differentiation;

- multi-extremity (multimodality);

- patching;

- lack of analytical expression (poor formalization) and high computational complexity of optimizing functions;

- high dimension of the search space;

- complicated topology of the region of permissible values, etc.

Fig. 1 presents the information technology of applying swarm algorithms (SA) for solving discrete optimization problems.

Information technology is as follows:

Stage 1. Analyze or DO problem is necessary for solving swarm algorithms. To do this, check the complexity and type of the task. If DO is necessary, then stage 2 .

Stage 2. Analyze the characteristics of the problem and the subject area for which it is necessary to solve the DO problem. For example, it is possible to build an initial population that is close to the optimal solution, and so can't be.

Stage 3. Based on the characteristics, SA type is determined, which is advisable to use to solve the DO problem.

Stage 4. Run the algorithm and analyze the resulting junctions.

There are trajectory and population search global optimization algorithms. Trajectory algorithms (single-state algorithms) suggest updating at each iteration the position of only one candidate in solving the problem. In this case, the total number of candidates may be greater than one, and at different iterations different candidates may move. In the swarm algorithms, firstly, the number of candidates (individuals) is greater than one. And, secondly, at each iteration, either all individuals move, excluding perhaps only some of them (for example, the «best» individuals), or at least a certain number of individuals, exceeds unity.

The general SA scheme is as follows:

1. Initialize the algorithm. Set the initial value of the count of the number of iterations $t=0$, the initial states of individuals $V_{i}(0), i \in \overline{1:|S|}$, that is, generate the initial population, and also set the value of the free parameters of the algorithm.

2. Carry out the evolutionary operators of this swarm algorithm for each of the components of the current vector $V_{i}=V_{i}(t)$, as a result of which the individual acquires a new position in the search area $X_{i}(t+1)=X_{i}^{\prime}$, a new search speed $\delta X_{i}(t+1)=\delta X_{1}^{\prime}$ and a new acceleration $\delta^{2} X_{i}(t+1)=\delta^{2} X_{i}^{\prime}$; $i \in[1:|S|]$.

3. Check the fulfillment of the conditions for the completion of the evolutionary process. If these conditions are not met, let's consider $t=t+1$ and return to stage 2 . Otherwise, take the best position of the individuals found as an approximate solution to the problem. 


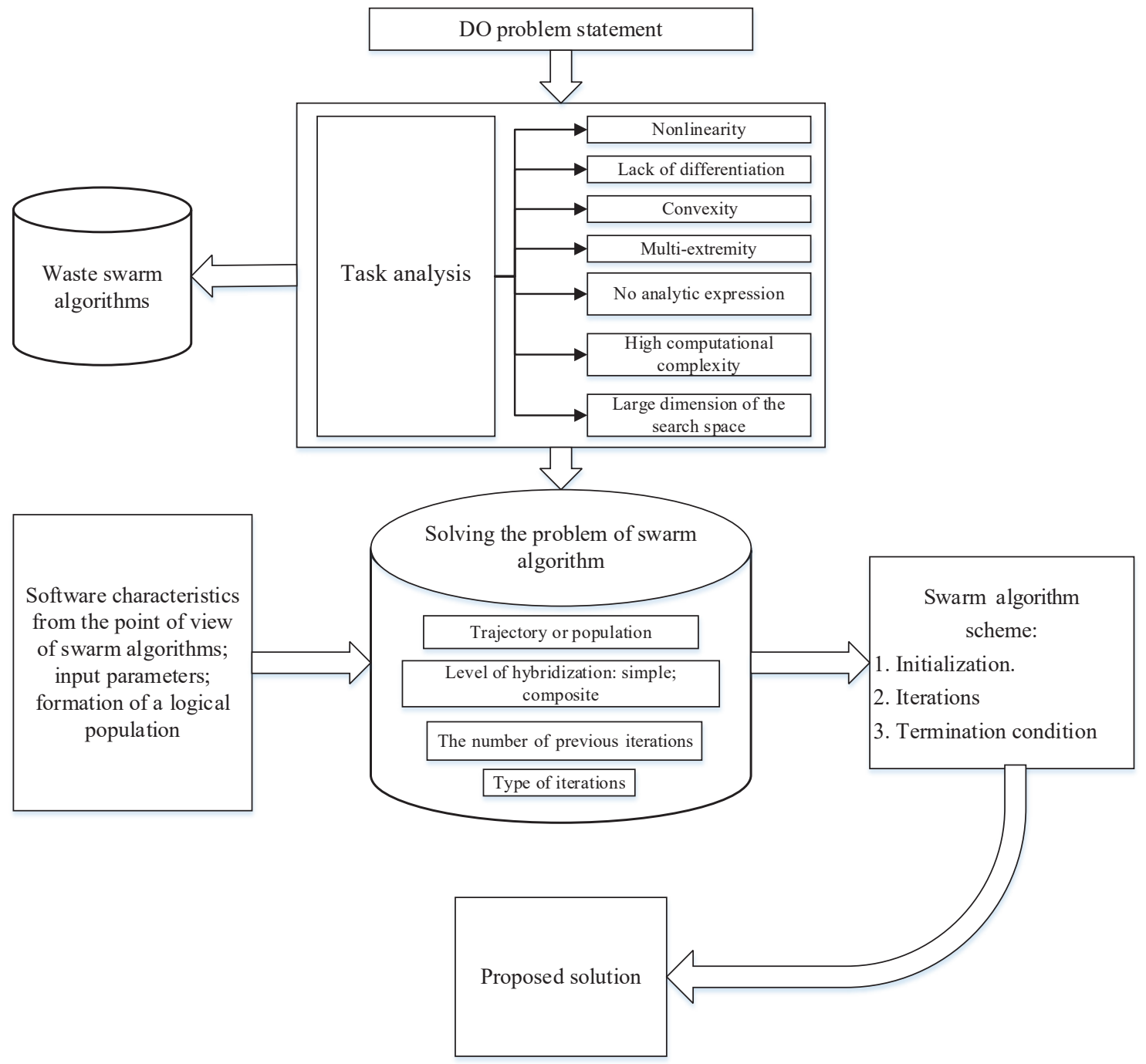

Fig. 1. Information technology of using swarm algorithms for solving discrete optimization problems

There are numerous examples of successful solutions using complex algorithms for global optimization, such as computer-aided design problems, the synthesis of complex chemical compounds, and optimal control of dynamic systems using swarm algorithms. Swarm algorithms are also successfully used in multi-criteria optimization algorithms, which involve the preliminary construction of some approximation of the Pareto set (front) of the corresponding multi-objective optimization problem.

The swarm algorithm (SA) is defined by a tuple with 7 signs (sets):

\section{$\mathrm{SA}=<\mathrm{FP}, \mathrm{SCP}, \mathrm{I}, \mathrm{P}, \mathrm{IO}, \mathrm{NPI}, \mathrm{IT}>$,}

where FP - free parameters; SCP - the space for combining populations; I - individual; $\mathrm{P}$ - population; IO the neighborhood of the individual; NPI - the number of previous iterations; IT - iteration type. All sets are finite and their elements can take the following values:

$\mathrm{FP}=\{$ static, dynamic $\}$ - the free parameters that are used in the SA can change during the operation of the algorithm (dynamic) or remain unchanged (static);

$\mathrm{SCP}=\{$ static, dynamic $\}-$ during the operation of the algorithm, the neighborhood metrics change (dynamic) or remain constant (static);
$\mathrm{I}=\{$ Type, Quality $\}$ - the place of an individual is determined by its type or quality (some weight function);

$\mathrm{P}=\{$ static, dynamic $\}-$ when combine populations, new individuals appear (dynamic), or everything that is (static) remains;

$\mathrm{IO}=\{$ static, dynamic $\}-$ during the operation of the algorithm, the neighborhood of an individual changes (dynamic), or remains constant (static);

NPI $=\{$ Single-step, Multi-step $\}-$ only the preliminary iteration (one-root) or the set of previous iterations (multistep) affects the next population;

$\mathrm{IT}=\{$ Simple, Complex $\}-$ iteration contains one process (simple) or several processes (complex).

In this paper, let's analyze 11 major SAs regarding their species according to the 7 signs. The results of the analysis are given in Table 2 .

This analysis allows you to build effective hybrid SAs, when the signs of one algorithm complement the signs of another. That is, the disadvantages of one algorithm can be covered by another algorithm. The information technology of such hybridization is shown in Fig. 2.

The research results are the developed information technologies for the use of swarm algorithms for solving problems of discrete optimization and hybridization of swarm algorithms. 
Table 2

Analysis of types of swarm algorithms to their attributes

\begin{tabular}{|c|c|c|c|c|c|c|c|c|}
\hline \multirow{2}{*}{ No. } & Properties & \multirow{2}{*}{$\begin{array}{c}\text { Free para- } \\
\text { meters } \\
\text { (static, } \\
\text { dynamic) }\end{array}$} & \multirow{2}{*}{$\begin{array}{l}\text { Space of asso- } \\
\text { ciation of popula- } \\
\text { tions (static, } \\
\text { dynamic) }\end{array}$} & \multirow{2}{*}{$\begin{array}{l}\text { Individual } \\
\text { (quality, } \\
\text { type) }\end{array}$} & \multirow{2}{*}{$\begin{array}{l}\text { Popula- } \\
\text { tion (static, } \\
\text { dynamic) }\end{array}$} & \multirow{2}{*}{$\begin{array}{l}\text { Neighborhood } \\
\text { individuals } \\
\text { (static, dy- } \\
\text { namic) }\end{array}$} & \multirow{2}{*}{$\begin{array}{l}\text { Number of } \\
\text { previous itera- } \\
\text { tions (one-step, } \\
\text { multi-step) }\end{array}$} & \multirow{2}{*}{$\begin{array}{l}\text { Itera- } \\
\text { tion type } \\
\text { (simple, } \\
\text { complex) }\end{array}$} \\
\hline & Algorithm & & & & & & & \\
\hline 1 & Continuous Ant Colony Dptimization & Static & Static & Type & Static & Dynamic & Multi-step & Simple \\
\hline 2 & Bee BA & Static & Static & Type & Static & Dynamic & Multi-step & Simple \\
\hline 3 & Bat-Inspired & Static & Static & Type & Static & Dynamic & Multi-step & Simple \\
\hline 4 & Fish School Search & Dynamic & Static & Quality & Static & Dynamic & Multi-step & Simple \\
\hline 5 & $\begin{array}{l}\text { Genetic Algorithm and Gaussian Mutation } \\
\text { Operator }\end{array}$ & Dynamic & Dynamic & Quality & Dynamic & Dynamic & Multi-step & Complex \\
\hline 6 & Particle 5warm Optimization & Static & Static & Quality & Dynamic & Dynamic & Multi-step & Simple \\
\hline 7 & Harmony Search & Static & Static & Quality & Static & Static & Multi-step & Complex \\
\hline 8 & Glowworm Swarm Optimization & Static & Static & Quality & Dynamic & Dynamic & Multi-step & Simple \\
\hline 9 & Stochastic Diffuse Search SDS & Static & Dynamic & Quality & Dynamic & Static & Multi-step & Simple \\
\hline 10 & Variable Mesh Optimization & Dynamic & Static & Duality & Static & Static & Multi-step & Simple \\
\hline 11 & Shuffled Frog Leaping Algorithm & Dynamic & Static & Quality & Dynamic & Dynamic & Multi-step & Simple \\
\hline
\end{tabular}

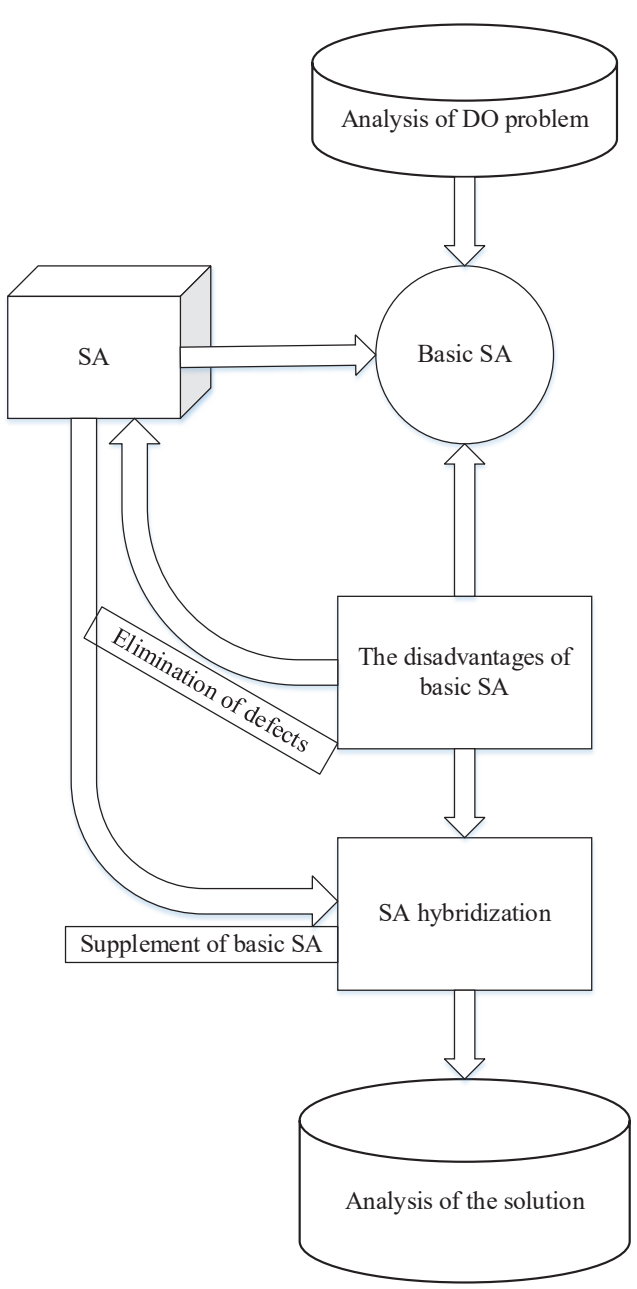

Fig. 2. Information technology of hybridization of swarm algorithms

\section{SWOT analysis of research results}

Strengths. Among the strengths of this research is that the application of the research can provide an opportunity to build effective hybrid SA, when the signs of one algorithm complement the signs of another and the disadvantages of one algorithm can be covered by another algorithm.

Weaknesses. The weak side of research is that to verify which of the algorithms will be suboptimal, to solve some optimization problem, expert advice from swarm intelligence is needed. Since there are many swarm algorithms, and the features of each swarm algorithm depend on the specifics of the investigated problem.

Opportunities. Opportunities that will provide a more effective result are the application and testing of the proposed method in Europe. For example, to test the method of calculating a safe position on fire potential at joint military exercises of Ukraine with partner countries. This approach will test the method for the effectiveness of its implementation.

Threats. The difficulty with the applied application of this method is due to the fact that it is only possible to verify effectiveness with the help of computer technology.

Thus, SWOT analysis of the research results makes it possible to determine that when searching for the necessary information technology in order to select a swarm algorithm for a particular domain task, it is necessary to use universal methods and technical equipment.

\section{Conclusions}

1. The problem of solving DO problems and reasonably promising solution of the problem of improving the efficiency of these systems through the use of methods of swarm intelligence are analyzed. This makes it possible to identify previously unsolved problems in the development of methods and tools for building decision support systems for solving DO problems. The classes of DO problems and methods for their solution using swarm algorithms are investigated. This makes it possible to scientifically substantiate the use of various methods of swarm intelligence depending on the class of DO problems.

2. An information technology is developed to use swarm algorithms depending on the class of the discrete optimization problem, based on the characteristics of swarm 
algorithms (type of input parameters, neighborhood of populations, type of formation of populations, type of iterative processes). This makes it possible to choose the relevant swarm algorithm for solving applied problems and to classify these tasks depending on the characteristics of the swarm algorithms that are used to solve it.

3. An information technology is developed using a combination of different methods of swarm algorithms for solving a certain class of problems, which, unlike other approaches, is based on a hybrid approach using swarm algorithms depending on their characteristics. This allows to take advantage of a specific swarm algorithm and thereby increase the efficiency of solving certain classes of applied discrete optimization problems.

\section{References}

1. Dorigo M., Stützle T. The Ant Colony Optimization Metaheuristic: Algorithms, Applications, and Advances // International Series in Operations Research \& Management Science. Boston: Springer, 2003. P. 250-285. doi: http://doi.org/10.1007/0-30648056-5 9

2. Adubi S. A., Misra S. A comparative study on the ant colony optimization algorithms // 2014 11th International Conference on Electronics, Computer and Computation (ICECCO). 2014. doi: http://doi.org/10.1109/icecco.2014.6997567

3. SinghJadon R., Dutta U. Modified Ant Colony Optimization Algorithm with Uniform Mutation using Self-Adaptive Approach // International Journal of Computer Applications. 2013. Vol. 74, Issue 13. P. 5-8. doi: http://doi.org/10.5120/12943-9931

4. The Bees Algorithm / Pham D. T. et. al. // Technical Note, Manufacturing Engineering Centre. Cardiff University. 2005.

5. Basturk B., Karaboga D. An artificial bee colony (abc) algorithm for numeric function optimization // IEEE Swarm Intelligence Symposium 2006. Indianapolis, Indiana, 2006.

6. Galchenko V. Ya., Yakimov A. N. Populiatsionnye metaevristichskie algoritmy optimizatsii roem chastits: handbook. Cherkassy: FLP Tretiakov A. N., 2015. 160 p.

7. Particle Swarm Optimization: Basic Concepts, Variants and Applications in Power Systems / Del Valle Y. et. al. // IEEE Transactions on Evolutionary Computation. 2008. Vol. 12, Issue 2. P. 171-195. doi: http://doi.org/10.1109/tevc.2007.896686

8. Coello C. A. C. An Introduction to Multi-Objective Particle Swarm Optimizers // Soft Computing in Industrial Applications. 2011. P. 3-12. doi: http://doi.org/10.1007/978-3-642-20505-7 1

9. Karpenko A. P. Populyatsionnye algoritmy global'noy optimizatsii. Obzor novykh i maloizvestnykh algoritmov // Prilozhenie k zhurnalu «Informatsionnye tekhnologii». 2012. Issue 7. P. 1-32.

10. Mirjalili S., Mirjalili S. M., Lewis A. Grey Wolf Optimizer // Advances in Engineering Software. 2014. Vol. 69. P. 46-61. doi: http://doi.org/10.1016/j.advengsoft.2013.12.007
11. Madadi A., Motlagh M. Optimal Control of DC Motor Using Grey Wolf Optimizer Algorithm // Technical Journal of Engineering and Applied Science. 2014. Vol. 4, Issue 4. P. 373-379.

12. Bat algorithm for constrained optimization tasks / Gandomi A. H. et. al. // Neural Computing and Applications. 2012. Vol. 22, Issue 6. P. 1239-1255. doi: http://doi.org/10.1007/ s00521-012-1028-9

13. BBA: A Binary Bat Algorithm for Feature Selection / Nakamura R. Y. M. et. al. // 2012 25th SIBGRAPI Conference on Graphics, Patterns and Images. 2012. P. 291-297. doi: http:// doi.org/10.1109/sibgrapi.2012.47

14. Yang X. S., He X. Bat algorithm: literature review and applications // International Journal of Bio-Inspired Computation. 2013. Vol. 5, Issue 3. P. 141-149. doi: http://doi.org/10.1504/ ijbic. 2013.055093

15. Kureychik V. V., Kureychik V. M., Rodzin S. I. Kontseptsiya evolyutsionnykh vychisleniy inspirirovannykh prirodnymi vychisleniyami // Izvestiya YUFU. Tekhnicheskie nauki. Tematicheskiy vypusk «Intellektual'nye SAPR». 2009. Issue 4 (93). P. 16-24.

16. Karpenko A. P. Sovremennye algoritmy poiskovoy optimizatsii. Algoritmy, vdokhnovlennye prirodoy: textbook. Moscow: MGTU im. N. E. Baumana, 2014. 446 p.

17. Bonabeau E., Dorigo M., Theraulaz G. Swarm intelligence: From Natural to Artificial Systems. Oxford University Press, 1999. 320 p.

18. Development of the method for territorial community formation based on multi-criteria swarm algorithm approach / Lytvyn V. et. al. // Technology Audit and Production Reserves. 2017. Vol. 3, Issue 2 (35). P. 20-27. doi: http://doi.org/10.15587/ 2312-8372.2017.105379

19. Modeling of the process of territorial communities formation using swarm intelligence algorithms / Lytvyn V. et. al. // Technology Audit and Production Reserves. 2017. Vol. 5, Issue 2 (37) P. 17-33. doi: http://doi.org/10.15587/2312-8372.2017.112198

Lytoyn Vasyl, Doctor of Technical Sciences, Professor, Department of Information Systems and Networks, Lviv Polytechnic National University, Ukraine, e-mail:yevhen.v.burov@lpnu.ua, ORCID:http:// orcid.org/0000-0002-9676-0180

Uhryn Dmytro, PhD, Associate Professor, Department of Information Systems, Chernivtsi Faculty of the National Technical University «Kharkiv Polytechnic Institute», Ukraine, ORCID: http://orcid.org/ 0000-0003-4858-4511

Olyvko Roman, Postgraduate Student, Department of Information Systems and Networks, Lviv Polytechnic National University, Ukraine, e-mail: oluvko07@gmail.com, ORCID: http://orcid.org/0000-0003$3740-2786$

Borovets Yaroslav, Postgraduate Student, Department of Information Systems and Networks, Lviv Polytechnic National University, Ukraine,e-mail:jarborx@gmail.com,ORCID: http://orcid.org/00000002-2379-5534 